\title{
Recurrent Extranodal Diffuse Large B-cell Lymphoma
}

National Cancer Institute

\section{Source}

National Cancer Institute. Recurrent Extranodal Diffuse Large B-cell Lymphoma. NCI

Thesaurus. Code C138015.

The reemergence of extranodal diffuse large B-cell lymphoma after a period of remission. 